\title{
U.S.-Turkey Relationship and Syrian Crisis
}

\section{Peerzada Tufail Ahmad*}

Abstract: $\quad$ The Syrian crisis is an amalgamation of strategic struggle for power and influence in the Middle East and the internal and external factors which are based on ethnic lines. Some are supporting the Assad regime, while as some are against it. The Syrian crisis has now transformed from a domestic or regional issue to a global security issue. The removal of Assad is a central step for both the Syrian people as well as the anti-Assad comp. However, after three years of fighting, the situation seems to be complex and without any possible outcome. In addition, the presence of extremists (ISIS) and a strong Iranian and Russian support for the regime, the Syrian crisis is jeopardizing the interests of both U.S. and Turkey. Both U.S. and Turkey have numerous national security interests at stake in Syria. However, the interests of both the countries do not perfectly match with each other. Turkey is unhappy about U.S's unwillingness to help the opposition to topple the Assad regime. Different priorities in the conflict have strained the bilateral relations. The aim of this paper is to analyse the U.S-Turkey relations in the light of recent Syrian crisis. An attempt will be made to highlight the issues which strain the bilateral relationship. This paper will highlight the divergent and convergent points in U.S-Turkey relations. This paper will also focus on U.S and Turkish policies vis-à-vis Syria. The policies of both the countries will be critically evaluated.

Key Words: $\quad$ U.S.-Turkey Relationship, Syrian Crisis.

* Ph.D Student in the Department of Political Science Aligarh Muslim University, Aligarh, U.P. India-202002. e-mail: pztufail.kat@gmail.com 


\section{Introduction}

The Syrian crisis, from a domestic issue has become a proxy war for a larger, strategic struggle for power and influence in the Middle East. The internal and external factors are prolonging the conflict and at the sometime ensure its complex, violent and uncertain course ${ }^{1}$. Internally the Syrian people are divided on ethnic lines. In addition, some are supporting the Assad regime, while as some are

| 12 against it. Externally, the regional and world powers are in a strategic struggle for power and influence in the region. The Syrian crisis has now transformed from a domestic or regional issue to a global security issue. Syria has become an example of a larger regional strategic competition between Sunni and Shia blocs. ${ }^{2}$ At the regional level, Syria is being turned into a battleground for sectarian agendas. On the other hand, at the global level, major power are concerned with the continuation of their vital interests. ${ }^{3}$

At the sometime, the crisis has manifested a strategic completion between pro-western bloc (Turkey, Saudi Arabia, Jordan etc) and anti-Western bloc (Syria, Iran, Russia and Lebanon). The removal of Assad is a central step for both the Syrian people as well as the anti-Assad comp. ${ }^{4}$ After three years of fighting, the situation seems to be complex and without any possible outcome. With almost a hundred thousand dead, millions displaced, the presence of extremists (ISIS), and a strong Iranian and Russian support for the regime, the Syrian crisis is now a global security challenge and at the some time is jeopardizing the interests of both U.S. and Turkey. ${ }^{5}$

U.S has numerous national security interests at stake in Syria like foiling Iran's aspirations for regional hegemony; lessening the dominance of political Islam; denying terrorists (ISIS) another safe haven; preventing the use of chemical weapons; stabilization of Iraq; and reducing a threat to Israeli security. ${ }^{6}$ As far as Turkey is concerned, instability in Syria is the single foreign policy challenge facing Turkey today. One of the main concerns for Turkish policy in Syria has been the political role of Syria's Kurds in particular and Kurds in general. ${ }^{7}$ In addition, the prolonged conflict endangers regional stability as the fighting continues to send refuges and violence into neighbouring countries, especially Turkey. ${ }^{8}$ The flow of refugees has strained Turkey's political, social as well as economic aspects.

In the meantime, U.S. influence inside Syria is currently limited. U.S. is not directly involved in the crisis. Its policy has been revolving around humanitarian issues and containing the influence of extremists. So, in order to safeguard its interests in Syria, U.S. will require the assistance and support of other regional as well as world powers. Turkey, a U.S ally with various interests in Syria, can clearly be an important partner. ${ }^{9}$

However, the interests of both the countries do not perfectly match with each other. Turkey is unhappy about U.S's unwillingness to help the opposition to topple the Assad regime. Also, disagreements between Turkey and the U.S. over which elements of Syrian opposition to support suggest that the two countries will have to overcome the divergent policies and work positively towards a peaceful solution of the conflict. ${ }^{10}$ Different priorities in the conflict have strained the bilateral relations. From the Turkish perspective, the U.S. policy is ambiguous and does not have any clear picture. U.S.'s 'ISIS first' approach does not coincide with the Turkish policy, which considers Assad regime's fall as its main foreign policy objective.

The aim of this paper is to analyse the U.S-Turkey relations in the light of recent Syrian crisis. An attempt will be made to highlight the issues which strain the bilateral relationship. This paper will highlight the divergent points in U.S-Turkey relations. This paper will focus on U.S and Turkish policies vis-à-vis Syria. The policies of both the countries will be critically evaluated. 


\section{1) Turkey-Syria Relations:}

Both Turkey and Syria had national interests in stability in the Middle East, countering terrorism and extremism, securing energy flows, and maintaining fruitful relations with Europe. ${ }^{11}$ However, the relationship between Turkey and Syria have been edgy due to some historical territorial disputes, which include Turkey's annexation of Hatay province in 1939, conflict over control of the Tigris and Euphrates water basin, Turkey's close relations with the West in general and Israel in particular, and Syria's support for the PKK in the 1980's and 1990's. ${ }^{12}$ Also, both the countries were on opposite sides in the cold war. Turkey was a founding member of NATO and Syria was the USSR's closet ally. ${ }^{13}$

In the 1990's Turkish policy toward Syria was defined by the security threat of Syrian support for the PKK. However, Abdullah Ocalan's expulsion in 1998 from Syria was a Turing point in bilateral relations. Since then, the bilateral relationship had shown some improvements. As a result over the past decade, Turkey developed wide relations with Syria. The new relationship was based on the framework of Turkey's self-declared 'zero problems with neighbours' policy. ${ }^{14}$

\section{2) Current Turkish Policy towards Syria:}

In March 2011, when the Assad regime started its violent and brutal crackdown on the protesters, Turkey did not cut its ties with Syria. Its response has been slow and since then has evolved. ${ }^{15}$ After the Assad regime's brutal approach to the opposition, Turkey begun to support the Syrian political opposition by hosting its members in Turkey. ${ }^{16}$

After Assad regime's continuing use of violence against its people, and more than nine thousand Syrians killed, Turkey suspended its diplomatic relations with Syria. In order to put more pressure on the regime, Turkey imposed sanctions on Syria. ${ }^{17}$ Developments in Syria have both contributed to sharpening an implicit competition between Turkey and Iran. ${ }^{18}$

Presently, the Turkish policy is based on the policy of defeating Bashar Al-Asad. At the same time, the aim of Turkish policy is the establishment of a no-fly zone, buffer zone or a safe-corridor. ${ }^{19}$ The aim is twofold: First, to stop the flow of refugees in Turkey and to settle them inside Syria in safe zones. Second, to work towards the regime's fall.

\section{3) Turkish Interests in Syria:}

Turkey has multiple interests at stake in Syria. Prominent among them to negate the influence of Kurds in Syria. The Syrian crisis has given new impetus to the Kurdish issue. In addition, Turkey has various interests in Syria. These are:

\section{a) Regional Aspirations:}

Turkey's aspirations to become a regional power have not been confined to the Middle East. Since 1989, Turkey has been involved in the Black Sea area, the Balkans, the Caucasus, and Central Asia as well. ${ }^{20}$ The US-led invasion of Iraq provided an opportunity for Turkey to actively engage with its neighbours. ${ }^{21}$

During the 2001 uprising in Syria, Turkey was testing the limits of its regional power and its capacity to lead the demand for revolution. Some argue that Turkey was trying to play the role of 'policy maker' country in the region. This was defined by some as 'neo-Ottomanism'. However, contrary to its expectations, Turkey encountered strong resistance in Syria. The policy failed to achieve its aim. ${ }^{22}$ 
Turkey has a big stake in the outcome of the conflict because of the two reasons: First, there is a big influx of refugees, and second, there is the Kurdish dimension of the crisis. Some believe that the Kurds might use the civil war as an opportunity to demand for an autonomous or even sovereign Kurdish region in Syria. The crisis has reopened the 'Kurdish issue'. ${ }^{23}$

\section{b) Kurdish Issue:}

The Kurds, an ethnic group are spread out in Iraq, Turkey, Iran, Syria, have long aspired to have their own state. Turkey continues to suffer from its prevalent Kurdish problem, and the Turkish Security mindset reflects a deep-seated fear of the state's territorial dismantlement. ${ }^{24}$ The Turkish government is watching the conflict closely. Turkey is concerned about cross-border spillover effects. ${ }^{25}$

The Syrian conflict has had a direct impact on the Kurdish question in Turkey. The conflict in Syria has drawn attention to the Kurdish minority there. The Syria Kurds are now more vocal than ever, and it is feared that in near future they might pronounce autonomy or even independence. ${ }^{26}$ Turkey's Kurdish issue is increasingly challenging Turkey domestically with regional implications.

c) Humanitarian Crisis:

The Syrian crisis is affecting the civilian population in the region, particularly women and children. More refuges are crossing Syria's borders every day to the neighbouring countries. ${ }^{27}$ The humanitarian situation continues to worsen as violence intensifies and fighting continues throughout the country. ${ }^{28}$

Over the last five years of conflict, as many as 220,00 people have been killed, 7.6 million have been displaced, 12.8 million are in need within affected population. The total number of Syrians registered in Turkey stood at 1,757,500, with another 255,562 Syrian refuges residing in shelters in 10 provinces. ${ }^{29}$

\section{4) Critical Evaluation of Turkish Policy:}

Some observers argue that Turkey did not have the diplomatic or military capability to play the role of 'rule maker' in the region. According to an International Strategic Research Organization (USAK) report, out of 135 Turkish diplomats working in over 20 Arab countries, only six were Arabicspeaking as of $2012 .{ }^{30}$ Some argue that Turkey over estimated its influence with Assad. They allege that the Turkish behaviour was more overconfident. Turkey assumed that they knew Syria despite the lack of Syria specialists in the Ministry of Foreign Affairs. They were clearly gaps in the Turkish knowledge and intelligence regarding Syria. ${ }^{31}$

When the uprising began in Syria, Turkey had three options: a) backing civilian opposition in addition to encouraging peaceful means; b) supporting military opposition with its own military capacity; and c) support military opposition with NATO assurance. It is argued that Turkey quickly dropped the first option, thought that the second option was possible and did not develop any serious policy for the third option. ${ }^{32}$ Critics argue that bridges were burned too quickly and Turkey swiftly adopted offensive stance. Turkey could have ended its ties without going so far as to back the opposition. However, the officials argue that its policy was based in line with most western thinking. ${ }^{33}$

Several observers initially assumed that Turkey had the military capability to overthrow the Assad regime. This notion was based on the events in 1998, when Turkey threatened the then Syrian president Hafiz-al-Assad with a military attack if Syria kept sheltering the PKK and its leader, Abdullah Ocalan. Syrian government immediately expelled Ocalan. ${ }^{34}$ 
Similarly, in may 2011, Erdogan declared that Turkey would not tolerate mass killings in Syria. This was interpreted as Turkish military operation against the regime. However, the lack of such action created disappointment. ${ }^{35}$

Turkey underestimated the toughness of pro-Assad forces and overestimated the willingness of the US and Europe to topple Assad regime from power. ${ }^{36}$ Turkish policy towards Syria has been 'misconceived', personal ideology-driven, and as such unstable. (pp.28-29). ${ }^{37}$

Turkey has been wrong in its predictions. First, there was a miscalculation on how long Assad would last and what he is capable of doing. Second, Turkey also miscalculated Assad's isolation. Third, Turkey's confidence in the Syrian opposition groups.(p.26). ${ }^{38}$ At the international level, Turkey's policies were prevented by the growing influence of the Iran-led Shiite bloc and the Saudi Arabia led Sunni bloc. The Iran-led Shiite bloc supported the Assad regime in Syria, while as the S. Arabia led Sunni bloc backed the military coup in Egypt. ${ }^{39}$

\section{5) U.S. Policy Towards Syria:}

Since 1980s the U.S. policy toward Syria has been focused on: to end Syria's support for Hezbollah and Palestinian extremists, encourage peace talks with Israel, and deal with Syria's chemical weapons and nuclear weapons. However, U.S. official view Syrian conflict as more of a humanitarian problem than as a direct threat to U.S. security. ${ }^{40}$ Unrest in Syria has the potential to affect U.S. national interests, most notably ending state sponsorship of terrorism, limiting the spread of weapons of mans destruction, and supporting human rights and development. ${ }^{41}$

Despite the gross violations of human rights and repeated breach of international norms, U.S failed to act properly. After Assad regime's brutal and forceful actions against the opposition, the U.S policy was misguided and U.S administration seemed to be indecisive about the next step. The U.S's inaction and misguided approach contributed to the deteriorating situation on the ground. The crisis does not seem to end soon and at the same time the possible solutions are grim. The crisis has, however, failed to stir a robust U.S response. ${ }^{42}$

As for as military intervention is concerned, the U.S. is against any kind of military intervention in Syria. ${ }^{43}$ However, the U.S. administration is divided on this issue. Some argue that US should intervene military in the Syrian crisis in order to protect civilian or to fulfill the stated U.S goal of removing Assad from power. However, the critics argue that the opposition forces that are not unified and may include groups with extremist views. Similarly, others argue that the establishment of 'safe havens' or 'no kill zones', as proposed by Turkey, may be viewed by the Assad government as a violation of sovereignty tantamous to a declaration of war. Likewise, some argue that military intervention could endanger the humanitarian work. (pp.15-17). ${ }^{44}$

However, with the emergence of ISIS, the US policy focused on assisting Syrians in combating the ISIS. This narrow approach has been resented by both Syrian political and opposition forces. U.S is facing several dilemmas regarding Syria as whole and with respect to ISIS. Some argue that an aggressive military campaign against the ISIS may take military pressure off the Assad regime or create opportunities for other extremist groups to advance. On the other hand, some argue that current US strategy lacks effective Syrian partners willing to advance against ISIS on the ground. Similarly, others argue that U.S strategy is based on flawed assumptions because it is not based on an inherently confrontational posture towards the Assad regime. ${ }^{45}$

At the same time, the U.S administration is focusing its strategy in Syria to alleviate terrorism threats and advance U.S goals for exit strategy in Iraq. The U.S policy is 'Iraq-first' ${ }^{46}$ U.S Policy in Syria and Iraq is being driven by 'ISIS first' and 'Iraq-fist' approaches. ${ }^{47}$ 


\section{6) U.S-Turkey Relations:-}

Throughout the cold war, the U.S.-Turkey had a clear strategic relationship. However, the relationship suffered over the issues of Cyprus, and Turkish internal governance. Turkey was the key player of a containment strategy that protected the West from communist expansion. However, with the collapse of Soviet Union, the central rationale for that framework disappeared. The U.S. and | 16 Europe continued to look on Turkey as an ally, but the raison d' etre of the alliance became unclear. ${ }^{48}$

For U.S., Turkey is instrumental in any strategy to stabilize and exit Iraq. ${ }^{49}$ Although Turkish, U.S interests are broadly convergent; the bilateral relationship remains heavily focused on security. However, rising levels of distrust has fueled Turkish security concerns. ${ }^{50}$

\section{i) Convergent Points:}

As for as Syrian uprising is concerned, initially both the U.S. and Turkey viewed it through the prism of the earlier revolution in Tunisia, Egypt and Libya. The Syrian crisis quickly escalated from a purely domestic conflict into an international crisis. ${ }^{51}$ The crisis exacerbated other regional issues such as regional competition between Iran and the Arab countries of the Gulf, Russia's quest for residual influence in the Middle East, and Israel security concerns. (p.9). ${ }^{52}$

With Turkey as a partner, U.S. would have an easier time fighting ISIS, stabilizing Iraq, if the U.S. chooses the course of ousting Assad. As, Turkey is the only NATO ally that borders Iraq and Syria, its absence or unwillingness will complicate any kind of strategy vis-à-vis Syria. So, both U.S. and Turkey needs to decide how much they need each other. ${ }^{53}$

\section{ii) Divergent Points:}

For more than half a century, a sound and good relationship with Turkey has been central to advancing U.S interests in the Middle East. However, the relationship have been strained largely over the Iraq war and the management of its aftermath. The relationship has now become less clear and U.S. and Turkish threat perceptions and interests are not as convergent as they once were. ${ }^{54}$

U.S.'s focus on Al-Qaeda and related terrorists groups, Iraq and Syria does not match with Turkey's worry with the PKK insurgency and Kurdish irredentism. (p.21). ${ }^{55}$ The Syrian crisis is placing tremendous strain on US-Turkey relations. The reason being rooted in differing priorities with relation to the Syrian crisis. As for as Turkey is concerned, its policy is focused on to bring down the Syrian regime while as U.S has focused its policy in fighting the ISIS. Both the countries need each other in any kind of settlement in Syria. ${ }^{56}$

The U.S's policy toward Syria is revolving around the fight against ISIS and the anti-ISIS coalition. Turkey, on the other hand is focusing on defeating Assad regime. Both the countries have different priorities and divergent policies. There have been instances when both the countries had divergent policies. For example, in the NATO Wales Summit from September 4-5, 2014 an establishment of the anti-ISIS coalition, Turkey was included as one of the core states joining the coalition. However, it did not put its signature on the Declaration in Jeddah. Similarly, Turkey did not grant access to Incirlik airbase for the coalition forces. It is believed that Turkey deliberately adopted this ambiguous attitude. The aim is to preventing a major crisis. Also, on the other hand, Turkey has been able to avoid becoming a target of ISIS, and has reassured its place within the western alliance.

Another occasion when both the countries seemed to be in opposite direction is, US's provision of direct assistance to the PYD despite Turkey's opposition. This created a rift between the two countries. The US's cooperation with the PYD, generated deep mistrust on the Turkish side.

Turkey wants the ISIS and Assad issues to be considered as one but the US has not conceded to these demands. Similarly, Turkey's plans of implementation of a no-fly zone, was not conceived positively by U.S authorities. 
Some observers point out that if a consensus on the Syrian issue remains absent, the Republicans might attempt to punish Turkey by passing bills in both chambers. This might heighten the anti-Americanism in Turkey. Also, if the Armenian issue receives the support of U.S., the political parties in Turkey might take advantage of these tensions.

Similarly, Turkey's request of Fatiullah Gulen's extradition might create new tensions in the bilateral relation. These divergences will endure in 2015 unless a major breakthrough changes the course of events. ${ }^{57}$

Turkey is angered by the U.S and NATO refusal or inability to intervene or to even aid Turkey in toppling Assad regime. This is due to the fact as U.S. administration does not view its vital interests involved and hence had to no desire intervene militarily. ${ }^{58}$ On the other hand, Turkey's lack of enthusiasm to get involved military against the fight ISIS creates doubts about its commitment to the anti-ISIS coalition. It is alleged that Turkey remains soft on ISIS and there has been perception that ISIS gets assistance from Turkey.

As for as Turkish policy is concerned, bservers believe that Turkey will maintain its current policy on Syria until U.S. spells clearly what its future plans are for that country. Also, Turkey is concerned that U.S. may in time come round accept Assad. Some argue that Turkey's stand on fight against ISIS is correct one because the government does not want to enter this war as it will be very messy for Turkey. For example, Ufuk Ulutas, the director for foreign policy at the Foundations for political, Economic and social Research (SETA), argues that Turkey's policy on ISIS is a correct one. He argues that the U.S. led operation is clearly unsuccessful. The coalition is pursuing a misguided strategy and Turkey should not be part of this. ${ }^{59}$

U.S-Turkish cooperation on Syria has not been effective from Turkey's perspective. The crisis has protracted the financial, human, and diplomatic costs for Turkey. ${ }^{60}$ The U.S. is adopting 'leading from behind' approach. Also, there has been reluctance on the part of U.S. to provide greater backing for the Syrian opposition, which has led Turkey to question the scope end depth of U.STurkish cooperation. ${ }^{61}$ Furthermore, international community demonstrated no desire for creating safe havens along the Syria-Turkey border. Turkey has been left alone and is frustrated by the lack of international support towards more concrete political action. ${ }^{62}$

Protracted chaos, sectarian violence and insecurity across the border is bound to affect the nature of Turkey's relations with the U.S and the west in general. Turkey is angered by the U.S and NATO refusal or inability to intervene or to even aid Turkey. (p.27) ${ }^{63}$ The international community is divided on Syria and no single country seems able to willing to lead a coalition to end the Assad regime. ${ }^{64}$

\section{7) Way Forward:}

Stable and importunate relations with the U.S. have always been a central aspect of Turkey's foreign policy. Both countries security priorities have long been strongly interdependent, with Turkey acting as a 'strategic partner' to the U.S. Since the end of World War II, regions like the Balkans Mediterean have been at the nexus of American and Turkish regional security strategies. ${ }^{65}$

The U.S. and Turkey have an opportunity to cooperate in helping to build a more democratic and thriving Middle East. Turkey is not only a good partner in this effort but also U.S's only partner with enough influence in the region. ${ }^{66}$ U.S. should engage Turkey on its plans to set up a safe area inside Syria. Similarly, Turkey needs to convince the U.S. to commit in principle this initiative. This is the sole remedy for the refugee problem. At the same time, U.S. should engage Turkey at the ministerial level to understand Turkey's objectives and establish common ground on the border Syrian crisis. ${ }^{67}$ 


\section{Notes}

${ }^{1}$ Mortan I. Abramowitz, Eric S. Edelman, "U.S.-Turkish Cooperation toward a Post-Assad Syria", Bipartisan Policy Center, April 2013, p 9.

${ }^{2}$ Ibid, p 5.

| $18{ }^{3}$ Erol Cebeci, Kadir Üstun, "The Syrian Quagmire: What's Holding Turkey Back”?, Insight Turkey, Vol.14, No.2, 2012, p 18.

${ }^{4}$ Mortan, U.S.-Turkish Cooperation Toward a Post-Assad Syria, p 5.

${ }^{5}$ Ibid, $\mathrm{p} 9$.

${ }^{6}$ Ibid, p 5 .

${ }^{7}$ Ibid, p 7.

${ }^{8}$ Ibid.

${ }^{9}$ Ibid, pp. 5-6.

${ }^{10}$ Ibid, pp. 6-7.

${ }^{11}$ J. Flanagan, Samuel J. Brannen, "Turkey's Shifting Dynamics: Implications for U.S-Turkey Relations", Centre for Strategic \& International Studies, June 2008.

${ }^{12}$ Ibid, p 14.

${ }^{13}$ Philip Robbins, Suits and Uniforms: Turkish Foreign Policy Since the Cold War, Hurst: London, 2003, p 99.; Christopher Philips, "Into the Quagmire: Turkey's Frustrated Syria Policy”, The Royal Institute of International Affairs, Briefing Paper MENAPBP 2012/04, Chatham House: London, 2012, p2.

${ }^{14}$ Erol Cebeci, The Syrian Quagmire, p 14.

${ }^{15}$ Robbins, Suits and Uniforms, pp. 382-384.

16 "Central Intelligence Agency (CIA) Handbook: Strategic Information, Activities and Regulations", International Business Publications: Washington DC, September 2, 2013, p 58.

${ }^{17}$ Madeleine K. Albright, (Ed.), "US-Turkey Relations: A New Partnership", Council on Foreign Relations, Independent Task Force Report No.69, May 1, 2012, p 41.

${ }^{18}$ Ibid.

${ }^{19}$ Mehmet Yegin, "Turkey-U.S. Relations: Embedded Disputes", The Journal of Turkish Weekly, February 4, 2015. http://www.turkishweekly.net/columnist/3933/turkey-u-s-relations-embedded-disputes.html

${ }^{20}$ Meltem Muftuler-Bac, Europe in Change: Turkey's Relations with a Changing Europe, Manchester University Press: UK, 1997, pp. 43-44.

${ }^{21}$ Andrew M. Dorman, Joyce P. kaufman (Ed.), The Future of Transatlantic Relations: Perceptions, Policy and Practice, Stanford University Press: California, 2011, p 147.

${ }^{22}$ Dogan Ertugrul, A Test for Turkey's Foreign Policy: The Syrian Crisis, TESEV: Istanbul, 2012, p 1.

${ }^{23}$ Kostas Ifantis, "The US and Turkey in the fog of Regional Uncertainty", Greese Paper No. 73, LSE; London, August 2013, p 23.

${ }^{24}$ Idrees Mohammad, "The Syrian Kurdish Issue in Turkish-Iranian-Iraqi Relations", Middle East Online, December 7, 2012.

${ }^{25}$ International crisis Group, "Syria's Mutating Conflict", Middle East Report No. 128, August 1, 2012, p 9.

${ }^{26}$ Fevzi Bilgin and Ali Sarchan (Ed.), UnderstandingTurkey's Kurdish Question, Lexington Books: United Kingdom, 2013, pp. 223-239; Chistopher M. Blanehard, (et el), "Armed Conflicts in Syria: Overview and U.S. Response", Congressional Research Service, April 9, 2014, p 1.

${ }^{27}$ International crisis Group, "Syria's Mutating Conflict", pp. 6-9; Michael Eisenstadt, "Syria After Assad: Heading Toward a Hard Fall", The Washington Institute, December 5, 2012; Ali Unal, "Turkish refugee Camps Provides Best Conditions", Daily Sabah, April 23, 2014.

28 "Syria Crisis ECHO Factsheet", European Commission Humanitarian Aid and Civil Protection ECHO Factsheet, March 12, 2014, p 2; UNFPA, "Regional Situation Report for Syria Crisis", Issue No.19, March 31, 2014; The Huffington Post, February 2, 2014.

${ }^{29}$ UNFPA, "Regional situation Report for Syria Crisis", Issue No.32, April 1-9, 2015, p 4.

${ }^{30}$ Ahmet T. Kuru, "Why did Turkish Policy Toward Syria and Egypt Fail"? Today's Zaman, July 30, 2014, http://www.todayszaman.com/op-ed_why-did-turkish-policy-toward-syria-and-egypt-fail_354020.html 
${ }^{31}$ Christopher Philips, Into the Quagmire, p 5.

${ }^{32}$ Kuru, Why did Turkish Policy Toward Syria and Egypt Fail?.

${ }^{33}$ Christopher Philips, Into the Quagmire, $\mathrm{p} 7$.

${ }^{34}$ Kuru, Why did Turkish Policy Toward Syria and Egypt Fail?.

${ }^{35}$ Ibid.

${ }^{36}$ Ifantis, The US and Turkey in the fog of Regional Uncertainty, pp. 20-21.

${ }^{37}$ Ibid, p 22.

${ }^{38}$ Ibid; Ertugrul, A Test for Turkey's Foreign Policy, p 3.

${ }^{39}$ Kuru, Why did Turkish Policy Toward Syria and Egypt Fail?.

40 Jeremay M. Sharp, Christopher M. Blanchard, "Syria: Unrest and U.S. Policy", RL3348, Congressional Research Service, May 24, 2012, pp. 9-10.

${ }^{41}$ Christopher M. Blanchard, Alex Arieff, (et el), "Change in the Middle East: Implications for U.S. Policy", Congressional Research Service, March 7, 2012, pp. 10-13.

${ }^{42}$ Kitu Bugra Kanat, A Tale of Four Augustus: Obama's Syria Policy, SETA: Ankara, 2015, pp. 9-12.

${ }^{43}$ Christopher, Syria: Unrest and US Policy, p 14.

${ }^{44}$ Ibid.

${ }^{45}$ Kenneth Katzman, "The 'Islamic State' Crisis and US Policy”, R43612, Congressional Research Service, 11 Feb, 2015, pp. 34-35.

${ }^{46}$ Ibid, p 35 .

${ }^{47}$ Ibid, p 11.

${ }^{48}$ Flanagan, Turkey's Shifting Dynamics, $\mathrm{p} 2$.

${ }^{49}$ Ibid, p 3.

${ }^{50}$ Ifantis, The US and Turkey in the fog of Regional Uncertainty, $\mathrm{p} 31$.

${ }^{51}$ Bulent Aliriza, Bulent Aras, "U.S-Turkish Relations: A Review at the Beginning of the Third Decade of the Post-Cold War Era”, SAM \& CSIS, November 2012, p 9.

52 Ibid.

${ }^{53}$ Sonar Cagaptay, "Is the U.S-Turkey Relationship Crumbling”, Policy Watch 2367, The Washington Institute, February 5, 2015.

${ }^{54}$ Flanagan, Turkey's Shifting Dynamics, $\mathrm{p} 1$.

${ }^{55}$ Ibid.

${ }^{56}$ Soner, Is the U.S-Turkey Relationship Crumbling.

${ }^{57}$ Yegin, Turkey-U.S. Relations: Embeded Disputes.

${ }^{58}$ Ifantis, The US and Turkey in the fog of Regional Uncertainty, p 27.

${ }^{59}$ Semih Idiz, "Turkey not expected to Revise Syria Policy", Almonitor, December 5, 2014. http://www.almonitor.com/pulse/originals/2014/12/turkey-syria-policy-not-expected-revise.html\#

${ }^{60}$ Aliriza, U.S-Turkish Relations, p 10.

${ }^{61}$ Ibid.

${ }^{62}$ Ifintas, The US and Turkey in the fog of Regional Uncertainty, pp. 21-22.

${ }^{63}$ Ibid, p 27.

${ }^{64}$ Cebeci, The Syrian Quagmire, pp. 13-14.

${ }^{65}$ Ebru Canan-Sokulu (Ed.), Debating Security in Turkey: Challenges and Changes in the 21th Century, Lexington Book: UK, 2013, p 18.

${ }^{66}$ Albright, US-Turkey Relations: A New Partnership, $\mathrm{p} 42$.

${ }^{67}$ Sonar, Is the U.S-Turkey Relationship Crumbling. 